\title{
Effects of Covid-19 Pandemic on Informal Sector's Women in Damak, Jhapa
}

- Gopal Khadka*,

\begin{abstract}
Economic sectors are broadly categorized as formal and informal sectors. Informal sector is also known as informal economy and grey economy. Informal sectors are beyond the monitoring system and tax system of government. To explore social and economic effects of Covid-19 on informal sector's women, this study is conducted as the title of effects of Covid19 pandemic on informal sector's women in Damak, Jhapa. It is based on the theoretical assumption of feminism. It employs exploratory research design and is based on both primary and secondary sources of data. The study revealed that there are very bad effects of covid-19 pandemicon women's livelihood, who are involved in informal economic sectors especially in street vending. The pandemic has indeed affected by decreasing the income of the women. The working condition in regards to hours of work per day and days of work per week has decreased significantly affecting the income. Additional problems such as less customer flow, low income, increased municipality eviction and lack of supplies of goods increased and led to indebtedness, and no saving at all during the pandemic. It suggests that concerned authorities should make effective institutional frameworks to empower women involved in informal sector of economy.
\end{abstract}

Keywords: pandemic, covid-19, grey economy, informal sector, feminism

\section{INTRODUCTION}

The newly identified infectious coronavirus (SARS-CoV-2) was discovered in Wuhan and has spread rapidly since December 2019 within China and to other countries around the globe (Zhou, 2020). The source of SARS-CoV-2 is still unclear (Gorbalenya, 2020). COVID-19 pandemic and lockdown created very bad effects on all aspects of society globally.

The coronavirus COVID-19 pandemic is the defining global health crisis of our time and the greatest challenge we have faced since World War Two. Since its emergence in Asia late last year, the virus has spread to most of the countries. Nepal, a landlocked country

\footnotetext{
* Mr. Khadka is an Assistant Professor of Rural Development, Patan Multiple Campus, TU, Nepal
} 
aspiring to graduate from a Least Developed Country status, stands highly vulnerable to the unfolding COVID-19 pandemic. Heedful of its vulnerabilities, the Government of Nepal has enforced a nationwide lockdown and activated its federal, provincial and local level mechanisms to respond to the crisis. While there is an urgent need to strengthen the existing health system to handle the situation in case of any sudden surge of outbreak, standardize the quarantine facilities and provide immediate relief to the most-affected, equally important is to help the country mitigate the socio-economic impacts and prepare for a longer-term recovery (UNDP, 2021)

The COVID-19 outbreak is impacting people all around the world, disrupting economic activities, state functions, livelihood options and it is reshaping global dynamics. People who were already vulnerable, might become even more vulnerable to traffickers who are exploiting global uncertainties to gain profits. Other individuals who are experiencing material, social and economic losses might find themselves at higher risks and other human rights violations. In countries that are implementing total or partial lockdown, persons might remain trapped in their place of exploitation and be unable to find an exit route. They might experience increased violence due to the loss of economic opportunities or they might be forced to keep working in unsafe conditions, without adequate health protections. Exploited persons might be obliged to work extra-hours to make more profits in a time of economic disruption. Law enforcement's efforts are focused on the prevention of COVID-19's spread and might reduce the capacity to respond. (Giammarinaro, 2020)

The current crisis caused by COVID-19 is bringing to the surface existing inequalities and vulnerabilities. The crisis might also represent a unique opportunity to implement universal social protection systems to erode sharper social inequalities. As affirmed by the Human Rights High Commissioner, COVID-19 is a test for societies, communities and individuals. The way States will react to this global crisis will set the foot for future generations and provide an opportunity to make societies fairer, more inclusive, and free from exploitation. (Giammarinaro, 2020)

The informal economy is a large and complex entity. At the first level, it is important to distinguish between two main types of activities in the informal sector: (I) Those which represent bare subsistence, such as street vending, and (ii) Those linked directly or indirectly with formal production). At another level, the informal economy is marked by heterogeneity of production modes. One can identify four main categories: (I) The use of hired wage labor; (ii) Self-employment and the use of family labor; (iii) Cooperative forms of production; and (iv) Hybrid forms combining different arrangements. Labor tends to move across these categories, indicating the precariousness of jobs in the informal sector. 
Subsistence activities such as street vending represent self-employed labor, and include some of the poorest social groups (Beneria\&Floro, 2004).

International Labor Organization indicates that informal entrepreneurship can be identified according to a number of characteristics. Those are, 1 . Production of goods by the individual for the household needs, 2. Production of goods and services for the purpose of earning profit, 3. Utilization of family labor without pay, 4. Relations between employee and employer being not resulted by laws and regulations, 5 . Payment of salaries to relatives of the family for their labor, 6. Being maintained as partnership ventures, 7. Obtaining workers from external sources. The above characteristics can be seen in informal entrepreneurship and while such businesses are carried out at home or at a rented location, the location where it is established too tends to be informal in nature (Dissanayake, 2005).

Informal sector in Nepal consists of all unorganized industrial and craft works, construction, garbage cleaning, forest product works, animal product works, agricultural works and various informal services. Women in informal sector supported to run their family smoothly. It has made them self-dependent as they did not have to seek financial help from others.

According to the Nepal Central Bureau of Statistics (2019), 62.2\% of the total workforce are engaged in the informal sector. High levels of informality in a country's economy is often characterized by various unwanted socio-political realities. Economists, political researchers, and government bodies alike associate the informal sector with widespread tax avoidance, irregular market prices, compromised quality of goods and services, and unregulated cash-based transactions (Khadka, 2021).

It is also universally understood that a prominent informal sector signals the prevalence of a large number of workers that are significantly vulnerable to low and fluctuating income, low social standing, exploitation, difficult working conditions, harassment, hostile social environment and deprivation from fundamental rights and legal protection (Khadka, 2021).

The ILO’s Decent Work agenda declares, just as Nepal 2015 constitution does, that it is a fundamental right of all citizens to be able to work and support themselves and their families irrespective of gender. However, the implementation of such paper declarations remains a distant reality in the Nepali context. CBS (2018) report shows that while the share of female employment in the informal sector is higher than that of men, as mentioned above, the converse share of women in the formal sector is dramatically low. A lack of technical know-how, market and investment knowledge, education and skills, personal property and savings or legal access to ancestral property and savings, which are often inherited exclusively by sons, familial constraints, and fierce competition with men and the already 
prevailing gender-based wage gaps often restrict women from exploring employment opportunities in the formal sector.

In Nepal, more than 70 percent of the economically active population is involved in the informal economy. Due to changing patterns of employment, the informal economy is rapidly expanding. However, workers in the informal economy face multiple of challenges and constraints because the government is not in a position to regulate it. Consequently, workers are subject to exploitation and deprived of many fundamental rights at work. Social protection for the workers in the informal economy is one of the emerging issues in Nepal (ILO, 2019). Improvement in living and working conditions of female informal workers leads to increased income and contributes to overall economic growth, and reduces poverty in the long term. Gender inequity in the informal economy should be addressed through development planning.

Gender paradox between men and women occurs through the process of socialization, strengthening and social, cultural, religious, even through state power (Handayani, 2008). Although economic function of the women in simple societies was not considered to be important, woman's role is a crucial factor in determining the economic growth in contemporary societies. In countries which are considered to be developed countries such as America, Canada as well as Britain, female entrepreneurs carry out a crucial function in the economy. However, women have relatively less participation in entrepreneurship of the poor countries (Maxfield, 2005).

This study is based on the key assumptions of cultural feminism to analyze the effects of COVID-19 pandemic on informal sector's women in study area. It shows that there is 'female nature' of 'female essence'. It assumes that due to the cultural attributes, there are different perspectives between male and female towards the same occupation, phenomena, event or object.

The term "cultural feminism" dates back at least to the use of it in 1975 by Brooke Williams of Redstockings, who used it to denounce it and distinguish it from its roots in radical feminism. Other feminists denounced cultural feminism as betraying feminist central ideas. Alice Echols describes this as the "depoliticization" of radical feminism. The work of Mary Daly, especially her Gyn/Ecology (1979), has been identified as a movement from radical feminism into cultural feminism (Lewis, 2019).

\section{OBJECTIVES}

This study has only one objective i.e. to explore the socio economic effects of COVID-19 pandemic on informal sector's women in Damak, Jhapa. 


\section{METHODS AND MATERIALS}

This study employs the exploratory research design to explore the effects of COVID-19 on study area. It is based on the idea offeminism. Bus park area of Damak Municipality is a study area. 50 women, who are involved in informal sector especially in street vending since two years were selected as respondents through purposive sampling procedure for detailed study about the effects of COVID-19 pandemic on their socio-economic life. It is based on both primary and secondary data. The primary data were collected through in-depth face-toface structured interviews and observations. The secondary data were collected by reviewing informal sectors and COVID-19 related literature through search engines. After Pretesting the questionnaire of in-depth structured interview, Data were collected with minute observation by the active initiation of the researcher himself. The collected data has been checked, coded, categorized, organized and converted into a master data sheet. Data was presented in Table and figure by using MS-word and MS-excel. Data is analyzed descriptively through percentage, frequencies and average mean value.

\section{RESULT AND DICUSSION}

\section{Nature of respondents}

Table-1: Characteristics of Sample Respondents

\begin{tabular}{|c|c|c|c|}
\hline \multicolumn{2}{|c|}{ Variables } & \multirow[t]{2}{*}{$\begin{array}{l}\text { Number of } \\
\text { respondents }\end{array}$} & \multirow[t]{2}{*}{ Percentage } \\
\hline & Ethnicity & & \\
\hline$\bullet$ & Brahmin & 10 & $20 \%$ \\
\hline$\bullet$ & Chhetri & 16 & $32 \%$ \\
\hline$\bullet$ & Janajati & 15 & $30 \%$ \\
\hline$\bullet$ & Madhesi & 9 & $18 \%$ \\
\hline \multicolumn{2}{|c|}{ Total } & 50 & $100 \%$ \\
\hline \multicolumn{4}{|c|}{ 2. Age groups(in years) } \\
\hline - & $20-30$ & 10 & $20 \%$ \\
\hline$\bullet$ & $30-40$ & 25 & $50 \%$ \\
\hline & $40-50$ & 15 & $30 \%$ \\
\hline \multicolumn{2}{|c|}{ Total } & 50 & $100 \%$ \\
\hline \multicolumn{4}{|c|}{ 3. Occupation } \\
\hline$\bullet$ & Farming & 45 & $90 \%$ \\
\hline & Non-farming & 5 & $10 \%$ \\
\hline \multicolumn{2}{|c|}{ Total } & 50 & $100 \%$ \\
\hline \multicolumn{4}{|c|}{ 4. Education } \\
\hline$\bullet$ & Illiterate & 10 & $20 \%$ \\
\hline$\bullet$ & Literate & 40 & $80 \%$ \\
\hline \multicolumn{2}{|c|}{ Total } & 50 & $100 \%$ \\
\hline \multicolumn{4}{|c|}{ 5. Level of education } \\
\hline & Primary & 30 & $75 \%$ \\
\hline$\bullet$ & Secondary & 8 & $20 \%$ \\
\hline
\end{tabular}




\begin{tabular}{|c|c|c|}
\hline Higher secondary & 2 & $5 \%$ \\
\hline Total & 40 & $100 \%$ \\
\hline \multicolumn{3}{|l|}{ 6. Religion } \\
\hline Hindu & 25 & $50 \%$ \\
\hline Buddhist & 10 & $20 \%$ \\
\hline Kirat & 15 & $30 \%$ \\
\hline Total & 50 & $100 \%$ \\
\hline \multicolumn{3}{|l|}{ 7. Family size(person) } \\
\hline $1-4$ & 20 & $40 \%$ \\
\hline $5-8$ & 30 & $60 \%$ \\
\hline Total & 50 & $100 \%$ \\
\hline \multicolumn{3}{|l|}{ 8. Number of children (person) } \\
\hline $1-2$ & 20 & $41.7 \%$ \\
\hline $3-4$ & 30 & $58.3 \%$ \\
\hline Total & 50 & $100 \%$ \\
\hline \multicolumn{3}{|l|}{ 9. Ownership of house } \\
\hline Rent & 35 & $70 \%$ \\
\hline Own house & 15 & $30 \%$ \\
\hline Total & 50 & $100 \%$ \\
\hline \multicolumn{3}{|l|}{ 10. Status of migration } \\
\hline Local & 15 & $30 \%$ \\
\hline - $\quad$ Migrated & 35 & $70 \%$ \\
\hline Total & 50 & $100 \%$ \\
\hline \multicolumn{3}{|l|}{ 11. Marital status } \\
\hline Married & 47 & $94 \%$ \\
\hline Divorced & 3 & $6 \%$ \\
\hline Total & 50 & $100 \%$ \\
\hline
\end{tabular}

Source: Field Survey, 2021

On the basis of table-1, respondents have heterogeneous nature in terms of age, ethnicity, religion, occupation and different other variables. No one ethnic group or caste group is in majority. In this study, Janjati group belongs to Gurung, Tamang, Rai and limbu people only. Most of the respondents belong to 20-50years' age groups. Most of them follow farming as their occupation and Hinduism, Buddhism and Kirat as their religion. Most of them (80\%) are literate. Majority (75\%) of literate respondents have completed primary level education. Most of them have a small familysize. They have up to 8 members in the family and up to 4 numbers of children. most of them are married. Majority of them are migrated from nearby places of Damak bus park. Majority of them (70\%) are residing in rented house. 


\section{Economic effects of covid-19 on informal sector's women}

Table-2 reveals the response of the respondents on the question related to economic effects of COVID-19. Most of the respondents agreed that the price of daily used goods are increased. Majority have a common agreed voice about the decrease of working days and hours per day Majority of respondent agreed that pandemic situation decreases their sources of income, which directly reduces their level of income and saving pattern. They realize to increase expenses on medicinal and educational sector. They have more expenses to manage online education to their children. Majority of respondents disagree to change their previous work after pandemic. Loss of employment of their family members, due to lock down frustrate them commonly. They are afraid that, they have burden to relief from debt and its interest.

Table-2: Effects of COVID-19 on Economic Situation

\begin{tabular}{|c|c|c|c|c|c|c|c|}
\hline SN & Variables & $(1)$ & $(2)$ & $(3)$ & $(4)$ & $(5)$ & Total \\
\hline 1 & Increase price of goods and services & $26 \%$ & $62 \%$ & $6 \%$ & $4 \%$ & $2 \%$ & $100 \%$ \\
\hline 2 & Decrease working days & $78 \%$ & $12 \%$ & $6 \%$ & $2 \%$ & $2 \%$ & $100 \%$ \\
\hline 3 & Increase medicinal expenses & $12 \%$ & $68 \%$ & $8 \%$ & $8 \%$ & $4 \%$ & $100 \%$ \\
\hline 4 & Increase educational expenses & $20 \%$ & $60 \%$ & $10 \%$ & $6 \%$ & $4 \%$ & $100 \%$ \\
\hline 5 & Decrease working hours & $90 \%$ & $4 \%$ & $2 \%$ & $2 \%$ & $2 \%$ & $100 \%$ \\
\hline 6 & Decrease the sources of income & $80 \%$ & $10 \%$ & $6 \%$ & $2 \%$ & $2 \%$ & $100 \%$ \\
\hline 7 & Decrease the level of income & $20 \%$ & $70 \%$ & $6 \%$ & $2 \%$ & $2 \%$ & $100 \%$ \\
\hline 8 & Decrease the level of saving & $30 \%$ & $50 \%$ & $20 \%$ & - & - & $100 \%$ \\
\hline 9 & Loss employment of family members. & $42 \%$ & $20 \%$ & $18 \%$ & $10 \%$ & $10 \%$ & $100 \%$ \\
\hline 10 & Change in previous work after pandemic & $10 \%$ & $12 \%$ & $14 \%$ & $16 \%$ & $48 \%$ & $100 \%$ \\
\hline 11 & Increase the level of debt & $40 \%$ & $40 \%$ & $10 \%$ & $6 \%$ & $4 \%$ & $100 \%$ \\
\hline
\end{tabular}

(Source: Field Survey, 2021) (1=Strongly Agree, 2=Agree, 3=Neutral, 4=Disagree, 5=Strongly Disagree)

Due to the response rate we can assume, that it is essential to launch an effective package to relief them from pandemic situation. Informal sector of economy especially street vending is women friendly. It has played a vital role in changing the lives of women in developing economies. Informal sectors are efficient to generating job opportunities at a very low cost. In many developing nations like Nepal, self-employment and small enterprises in the 
informal sector can absorb some workers who had lost their jobs in the formal economy. By realizing the importance of informal sector, Central, provincial and local level government should play vital role for its promotion.

\section{Social Effects of COVID-19 on Informal Sector's Women}

Table- 3 reveals the response of the respondents about the effects of COVID-19 related to social aspects. Majority of respondents agreed that the lock down due to COVID-19 reduced their work load of economic activities and increase leisure time. It has reduced the frequencies of social interaction among friends, clients and suppliers. Majority of the respondents agreed that due to lock down, their workload in household activities are increased for cooking, cleaning, washing and other domestic works. Majority of them use their leisure time in rest and involved in entertaining and informational programs on Radio and TV. Most of them spent their time in interaction with family members and relatives through social media. A majority woman responds that high frequency of family interaction helps to understand the problems of family and manage them on time. They have enough time to motivate their children about homework. They can spend more time with family members.

They are unable to involved in social work. They are unable to visit religious places and celebrate feast and festivals. Most of them reported that, the frequencies and volume of time is increased for using social media such as Tik-Tok, Facebook, you tube etc. Majority of women respond that they feel burden to manage online classes for their children and to provide health facilities for family members.

Table-3: Social Effects of Covid-19 on Informal Sector's Women.

\begin{tabular}{|c|l|l|l|l|l|l|l|}
\hline SN & Variables & $(1)$ & $(2)$ & $(3)$ & $(4)$ & $(5)$ & Total \\
\hline 1 & Increase leisure time & $60 \%$ & $30 \%$ & $4 \%$ & $4 \%$ & $2 \%$ & $100 \%$ \\
\hline 2 & Decrease Social interaction & $50 \%$ & $40 \%$ & $6 \%$ & $2 \%$ & $2 \%$ & $100 \%$ \\
\hline 3 & Increase family burden & $30 \%$ & $58 \%$ & $8 \%$ & $2 \%$ & $2 \%$ & $100 \%$ \\
\hline 4 & Involve in family interaction & $38 \%$ & $50 \%$ & $10 \%$ & $2 \%$ & - & $100 \%$ \\
\hline 5 & Involve in social work & $4 \%$ & $6 \%$ & $16 \%$ & $24 \%$ & $50 \%$ & $100 \%$ \\
\hline 6 & Involve in feast and festivals & - & - & $10 \%$ & $10 \%$ & $80 \%$ & $100 \%$ \\
\hline 7 & Visit religious places & $2 \%$ & $6 \%$ & $16 \%$ & $20 \%$ & $56 \%$ & $100 \%$ \\
\hline 8 & Involve on social media & $20 \%$ & $70 \%$ & $6 \%$ & $2 \%$ & $2 \%$ & $100 \%$ \\
\hline
\end{tabular}




\begin{tabular}{|c|l|l|l|l|l|l|l|}
\hline 9 & Problems on child's education & $40 \%$ & $50 \%$ & $4 \%$ & $4 \%$ & $2 \%$ & $100 \%$ \\
\hline 10 & Problems to get health facilities & $42 \%$ & $52 \%$ & $2 \%$ & $2 \%$ & $2 \%$ & $100 \%$ \\
\hline
\end{tabular}

(Source: Field survey, 2021). (1=Strongly Agree, 2=Agree, 3=Neutral, 4=Disagree, 5=Strongly Disagree)

\section{CONCLUSION}

Women working in informal sectors are beyond the protection of labor laws and social security such as health insurance, pension, paid sick leave etc. They are compelling to work for minimum wages, unhealthy environment and unsafe condition. They have high risk of sexual abuse and sexual harassment. Due to the lack of social protection in informal economic sectors, women faces multiple bad impacts on their livelihood.

Considering the importance of informal sector in economy, local government should announce areas for street vending or restricting the vending activities. Fund to be allocated to capacitate and empower them through skill trainings. Since pandemic is prone to occur in future, even the vendors should start saving immediately for future emergencies for which they can approach formal institutions such as banks and women cooperatives. I/NGOs focus should be on the informal workers more specifically on street vendors, and develop projects to provide skill development and livelihood trainings. Researchers should make further research or studies on women street vendors specifically focusing on their income and serious impact of pandemic or health emergencies.

Women groups of informal sector must be formed and launch women empowerment programs. Provision of soft loans by financial institutions should be managed with group collateral. It creates direct benefits to women through their group solidarity politically, socially and economically. Concerned authority must understand needs and concerns of informal sector's women.

\section{REFERENCES}

Beneria, L. and Floro, M. (2004) "Distribution, Gender and Labor Market in formalization: A Conceptual Framework with a Focus on Homeworkers”, manuscript.

CBS. (2018).Nepal labor force survey-2018.Ktm .nepal

Dissanayake, D., (2005). Female Participation of Informal Economic Activities in Sri Lanka. Colombo: The Department of Census and Statistics.

Giammarinaro, Maria Grazia. (8 june 2020). COVID-19 Position paper The impact and consequences of the COVID-19 pandemic on trafficked and exploited persons. Retrieved from COVID-19-Impact-trafficking.pdf (ohchr.org)

GorbalenyaA.E. (2020) The species severe acute respiratory syndrome-related coronavirus: classifying 2019-nCoV and naming it SARS-CoV-2. Nat. Microbiol

Handayani, T. (2008). KonsepdanTeknikPenelitian Gender EdisiRevisi. Malang: UMM Press 
ILO. (2019). Women in the Informal Economy: a statistical picture. Geneva: International Labor Office. International labor organization. (2019). Informal economy in Nepal. Retrieved from Informal economy in Nepal (ILO in Nepal)

Khadka, S., (25 February 2021). women working in Nepal's informal sector. [Blog post] Retrieved from Women Working in Nepal's Informal Sector (gmcnepal.org)

Lewis, J.J. (2019 may 30).cultural feminism. Retrieved from https:// www.thoughtco.com/culturalfeminism-definition-3528996

Maxfield, S., (2005). The Entrepreneurship Gender Gap in Global Perspective: Implications for Effective Policymaking to Support Female Entrepreneurship. [Online] Available: http://www.gdro.org/icm/micro/define-micro.html (July 26, 2010)

Regan, C. (2012 Oct 2). women and development. Development education. Retrieved from https://developmenteducation.ie/feature/women-development/

UNDP. (2021). COVID-19 pandemic response. Retrieved from https://www.np.undp.org/content/nepal/en/home/coronavirus.html

World Bank. (2011). world development report 2012: gender and development. Washing DC.

Zhou P. A. (2020) pneumonia outbreak associated with a new coronavirus of probable bat origin. Nature. 2020;579(7798):270-27 